\title{
Gut hormones in glucose homeostasis
}

\author{
BY V. MARKS, LINDA MORGAN, J. OBEN AND R. ELLIOTT \\ School of Biological Sciences, University of Surrey, Guildford GU2 $5 X H$
}

Glucose is the only sugar to circulate in the blood in more than trivial amounts. It is, for all practical purposes, the only source of energy for the brain, which extracts glucose from the blood at a more or less constant rate throughout the day and night. Despite its obvious importance to energy economy, the total amount of glucose in the body after an overnight fast is only $10-15 \mathrm{~g}$, corresponding to a blood glucose concentration of $4-6$ $\mathrm{mmol} / \mathrm{l}$. The body pool of glucose is contained almost exclusively within the extracellular water and, in the fasting subject, glucose is delivered into it by the liver at a rate of about $9 \mathrm{~g} / \mathrm{h}$. Intermittently, the fasting state is interrupted by the ingestion of food, which provides something in excess of $300 \mathrm{~g}$ carbohydrate $/ 24 \mathrm{~h}$, mainly in the form of glucose and its polymers.

Before the days of insulin therapy for diabetes, all this glucose and more was excreted from the body in the urine of insulinoprivic-diabetic subjects following the ingestion of carbohydrate-containing meals. With it went large quantities of water and salt from which the sufferers from diabetes rapidly succumbed.

Healthy subjects, in contrast to diabetic patients, were known to be able to tolerate up to $300 \mathrm{~g}$ carbohydrate given in a single load, as glucose in solution, if needs be, without losing glucose into their urine and with only minor perturbations in blood glucose concentration (Peters \& van Slyke, 1946; Marks, 1987). This remarkable feat of homeostasis is now known to be achieved by a co-ordinated physiological response to the ingestion of food, the two main effectors of which are: (1) limitation on the delivery of glucose into the pool, i.e. the maximum rate of glucose absorption; (2) the rate of disposal of glucose into the tissues, which is itself mainly a consequence of increased insulin action.

It is not intended here to examine in detail the many factors that limit the rate of glucose absorption, except to draw attention to the central role played by the regulation of gastric emptying by both neural and hormonal mechanisms and which are themselves responsive to the presence of absorbable nutrients in the duodenum, jejunum and probably ileum. Instead we will examine the role of hormonal agents released by endocrine cells within the intestinal mucosa, which, either by stimulating insulin secretion or by direct action on peripheral tissue, increase the rate of glucose assimilation.

\section{ABSORPTION AND DISPOSAL OF A GLUCOSE LOAD}

It was known even before the isolation of insulin, that following the ingestion of oral glucose solutions there was a modest but brief rise in capillary (arterial) blood glucose, the magnitude of which was independent of dosage, providing it was greater than about $30 \mathrm{~g}$ (Foster, 1923). Although peak levels of blood glucose were achieved within about $30 \mathrm{~min}$ of ingestion regardless of dose, the decline that occurred thereafter in blood glucose concentration, and the time taken for blood glucose to return to basal levels, was slower with the larger (e.g. $200 \mathrm{~g}$ ) than with the smaller (e.g. $30 \mathrm{~g})$ doses. Often it had not returned completely to basal levels up to $5-6 \mathrm{~h}$ after ingestion, even of a liquid glucose meal. 
The difference in the time taken to return to basal blood glucose levels is much smaller if venous, rather than arterial, blood glucose concentrations are measured (Marks \& Morgan, 1984). This is due to the large arterio-venous (AV) glucose differences that obtain under these circumstances, and are seen with big but not with small glucose loads. The AV difference is associated with a sustained hyperinsulinaemia which is comparable in magnitude even late in the absorptive process, when blood glucose levels have fallen well below their peak, to that seen during the early phase of maximal post-prandial hyperglycaemia.

Before the production of evidence by McIntyre et al. (1964) that intestinal factors released specifically in response to the presence of glucose in the small intestine were capable of stimulating insulin release, it had been assumed that the most important, if not only, determinant of insulin secretion was the concentration of glucose in blood perfusing the pancreatic islets. The suspicion by McIntyre et al. (1964) that these factors were largely if not entirely hormonal in nature and exerted their effect by augmenting the insulin-stimulatory properties of glucose rather than independently, has been amply confirmed on numerous occasions. Doubts that were cast on the whole concept of an entero-insular axis have been shown to be groundless and the result mainly of methodological errors (Hampton et al. 1986). Nevertheless the magnitude of the effect and the exact nature of the humoral factors responsible are still poorly understood, as are their physiological importance and pathological consequences of malfunction.

The concept of an incretin, first put forward in the 1930s but dismissed until revived by McIntyre et al. (1964) presupposed that a hormone secreted by the gut in response to the ingestion of food either amplified the insulin-stimulatory properties of glucose or affected its disposal directly. None of the gastrointestinal hormones (Marks \& Samols, 1970) that were known about and purified at the time of the rediscovery of the entero-insular axis, i.e. secretin, gastrin, pancreozymin-cholecystokinin (PZ-CK) meet the requirements of an incretin (Creutzfeldt, 1979; Creutzfeldt \& Ebert, 1985), although each has been proposed for this role by one or more groups of investigators and discarded as more evidence of their physiological rather than their pharmacological properties emerged (Shuster et al. 1988). An earlier suggestion (Samols et al. 1965; Samols et al. 1966; Samols \& Marks, 1967), that an uncharacterized immunoreactive glucagon-like material released from the gut in response to the ingestion of carbohydrate might be involved in the entero-insular axis, received little support and was quietly dropped by most people except ourselves.

\section{GASTRIC INHIBITORY POLYPEPTIDE (GIP)}

Little more than 8 years after McIntyre et al.'s (1964) seminal paper appeared. GIP was isolated by Brown et al. (1970) from a crude preparation of pancreozymin in their search for an enterogastrone. This was the hormone postulated to exist and explain the suppression of gastric acid secretion that follows ingestion of a meal.

Within a couple of years of its discovery, GIP emerged as the strongest candidate for the role of intestinal mediator of the augmentation of insulin secretion that is observed to follow the ingestion of a meal (Dupré et al. 1973: Turner et al. 1973, 1974; Marks \& Turner, 1977). The physiological behaviour and pharmacological properties of GIP (Brown, 1982; Creutzfeldt \& Ebert, 1985) that qualify it for serious consideration as the hypothetical mediator of the incretin effect include: 
(a) its production by specific $(\mathrm{K})$ cells which are confined to the duodenal and jejunal mucosa of the gut;

(b) its release into the circulation in response to the absorption of glucose but not of fructose and other sugars or polyols which do not stimulate insulin release when taken by mouth, or do so only to the same extent as when given intravenously;

(c) its secretion by the $\mathrm{K}$ cells in response to the ingestion of galactose which stimulates insulin release when taken orally, but not when given intravenously (Samols \& Marks, 1967; Marks, 1970; Sykes et al. 1980) and utilizes the same active transport system as glucose;

(d) its ability to stimulate $\beta$-cells to secrete insulin in the presence of modest hyperglycaemia and at concentrations comparable with those observed in blood following ingestion of a carbohydrate-containing meal, but not when blood glucose levels are basal or sub-basal.

GIP release from the intestinal mucosa occurs more or less immediately after a meal which contains absorbable carbohydrate and fat is eaten and its concentration in the plasma remains elevated for as long as there is still food in the intestinal lumen (Marks \& Morgan, 1984).

In most healthy human beings plasma GIP levels do not fall to basal levels until many hours after eating (Service \& Nelson, 1980; Arendt et al. 1982). GIP, therefore, provides a very neat explanation as to how and why plasma insulin levels rise so soon after ingestion of a meal (Andersen et al. 1978; Takemura et al. 1982; Elahi et al. 1984) and remain elevated for long after arterial blood glucose levels have reached their peak and venous blood glucose levels have returned to normal basal values.

It is, however, well appreciated that although still unrivalled as the main candidate for the role of chief mediator of the incretin effect GIP cannot alone explain all the observed phenomena (Creutzfeldt \& Ebert, 1985).

Some of the evidence that has been put forward to diminish its role is spurious (Sarson et al. 1982) and based on a misunderstanding: namely that the immunoreactivity of porcine and human GIP, which differ by only one amino-acid residue, is the same and that the two different types of GIP behave identically in all immunoassays. Although they do in some (Morgan et al. 1978), they do not in others.

Attempts were made to adjust the rate of exogenous porcine GIP infusions in order to match endogenous (human) GIP levels in volunteers following the ingestion of meals and compare the insulinotropic effects (Sarson et al. 1982). The immunoassay used recognized porcine GIP, to which the antiserum had been raised, much more avidly than human GIP. Consequently it gave incorrect information as regards the level of endogenous human GIP against which the infused porcine GIP was matched.

The results were construed as showing that GIP is insufficiently potent as an insulinotropic agent, at the concentration at which it was thought to circulate in blood after a meal, to make it a serious contender for the role of the major incretin.

Misconstruction of the potency of endogenous GIP as an insulin secretagogue was not helped by the fact that the first amino-acid sequence of porcine GIP that was published was incorrect (Brown \& Dryburgh, 1971). As a result synthetic GIP made to the formula had virtually no insulinotropic properties. It was, nevertheless, a fully potent enterogastrone (Taminato et al. 1977), confirming that the two properties of the GIP molecule are separate. 
Immunoneutralization of GIP with antiserum in rats, whilst reducing the incretin effect of oral glucose, does so by only $50 \%$ (Ebert \& Creutzfeldt, 1982). This adds weight to the suggestion that in rats, and probably other species in which there is a potent entero-insular axis, at least one other enteric humoral factor is involved in the alimentary augmentation of glucose-stimulated insulin release (Creutzfeldt \& Ebert, 1985).

\section{GUT GLUCAGON-LIKE PEPTIDES}

The presence of glucagon or glucagon-like peptides in the gut was predicted by Makman $\&$ Sutherland (1964) on the ability of gut mucosal extract to stimulate the production of cyclic AMP in tissues in exactly the same way as pancreatic glucagon. Samols et al. (1966) showed that not only were there biological but also immunological glucagon-like substances (GLI) distributed throughout the length of the gastrointestinal tract. The immunological properties of these GLI were slightly different from those of pancreatic glucagon and from one another in the various parts of the intestine.

GLI was found to be released into the circulation in response to the ingestion of glucose as well as to galactose. This sugar shares an active transport system with glucose but unlike glucose stimulates insulin secretion only when taken orally; not when given intravenously (Samols \& Marks, 1967; Morgan et al. 1979). Fructose, which stimulates insulin secretion neither when given orally nor intravenously, except in a minority of persons, had no stimulatory effect on gut glucagon release. Since the nature and biological properties of intestinal GLI were not known at the time it was assumed that, like pancreatic glucagon, it stimulated the release of insulin (Marks \& Samols, 1970). With the isolation of a number of non-insulin-stimulatory glucagon-like peptides from the gut the initial concern with them as possible mediators of the incretin effect waned (Marks \& Turner, 1977).

Recently, however, a glucagon-like peptide (GLP-1 (7-36) amide), with even more potent insulin-releasing properties than GIP or glucagon itself, and which is found in greatest concentrations in the ileum, has revived the former interest in GLI as possible incretins (Holst \& Bersani, 1991).

\section{GIP-1, GLP-1, (7-36) AMIDE, AND GLP-2}

As a result of advances in the molecular biology of the preproglucagon gene it became clear during the early 1980 s that whilst in the A-cells of the pancreas the main cleavage products of preproglucagon are glucagon itself and a large glucagon fragment, this did not happen in the corresponding cells of the small intestine. In these the cleavage products include three glucagon-like peptides known as GLP-1, GLP-2 and GLP-1 (7-36) amide (also known as truncated (tGLP-1) but not 'pancreatic' glucagon itself (Holst et al. 1991).

GLP-2 has no insulin-releasing properties and those of GLP-1 are extremely weak and exerted only under certain non-physiological conditions. GLP-1 $1_{(7-36)}$ amide on the other hand is the most potent stimulator of insulin secretion in the presence of hyperglycaemia yet discovered both in vivo and in vitro. Moreover, it is released into the circulation in response to the ingestion of carbohydrate-containing meals (Kreymann et al. 1987). Unlike GIP, which stimulates pancreatic glucagon secretion both in vivo and in vitro, 
GLP-1 $1_{(7-36)}$ amide suppresses it. This effect has generally been considered as due to a direct inhibitory effect of GLP-1 (7-36) amide on the A cells. It is, however, seen only at concentrations of GLP-1 (7-36) amide some ten times higher than that at which it stimulates insulin secretion (Komatsu et al. 1989). The inhibitory effect on glucagon secretion may, therefore, be mediated through the intra-islet portal system, wherein insulin inhibits pancreatic glucagon secretion, rather than by direct action on the A cells (Samols \& Stagner, 1991).

This explanation is rendered the more likely by the fact that in completely insulinoprivic subjects oral glucose administration stimulates, presumably through GIP release, rather than reduces pancreatic glucagon secretion, as would be expected if GLP-1(7-36) amide was inhibitory of pancreatic glucagon secretion in its own right especially as insulin deficiency appears to increase ileal GLP-1 $(7-36)$ amide production (Göke et al. 1991).

\section{MEASUREMENT OF GLUCAGON-LIKE PEPTIDES}

If the measurement of GIP in plasma has been difficult, because of differences in assay sensitivity, specificity and standardization, then that of glucagon-like peptides has been horrendous, dating back to the very beginnings of immunoassay for peptide hormones. This is not the place to go into this very vexed question which is still unresolved and likely to remain so until international quality assurance schemes for glucagon-like peptides in plasma, comparable with those available for simpler analytes, become generally available and applied. Suffice at this stage to say that whilst there is clear evidence that GLP-1 ${ }_{(7-36)}$ amide does circulate in human blood and does increase in concentration in response to the ingestion of carbohydrate-containing meals (Kreymann et al. 1987), there is considerable doubt as to its absolute concentration both in the fasting and fed states.

Some if not all of the rises in the plasma concentration of glucagon-like materials (CRM) that were reported under diverse conditions in the past can be explained in part, if not wholly, by imperfections in the assays employed. Probably none were as specific as their authors supposed, largely because the major potential cross-reactant had neither been identified nor become available for investigation.

If, for example, the antisera used in the radioimmunoassays of the time had had greater affinities for GLP-1, GLP-1 (7-36) amide, GLP-2 or other intestinal glucagon cross-reactants than for the 'standard'. i.e. native pancreatic glucagon, unrealistically high 'absolute' values for 'gut-glucagon' would have been obtained; as indeed they were (Samols et al. 1966). The direction of the changes in concentration that were observed and the stimuli to them would have been real, however.

Results from our own laboratory using an assay for plasma GLP-1 (7-36) $_{\text {amide, which }}$ we believe to be as sensitive as any so far described, and more specific than most, lead us to believe that whilst fulfilling many of the criteria for an incretin, GLP-1(7-36) amide does not circulate in peripheral blood in man at concentrations sufficiently high, either in the basal or stimulated state, to make it more than a minor contributor to the overall incretin effect. This is in contrast to piglets in which a very marked increase in plasma GLP-1 ${ }_{(7-36)}$ amide occurs in response to a meal, from basal levels of $5 \mathrm{pmol} / 1$ to mean stimulated levels greater than $50 \mathrm{pmol} / \mathrm{l}$.

In this context it is perhaps relevant that man is a species in which a relatively high proportion of energy is supplied by dietary fat. In other species (and possibly some human beings) which rely almost entirely on slowly absorbed carbohydrate for their 
energy intake it is possible that GLP- $1_{(7-36)}$ amide and the other glucagon-like peptides have a larger role to play in exercising the incretin effect as well as in the conversion of carbohydrate into fat.

There is already some evidence that just as alterations in diet can induce changes in GIP production and secretion (Morgan et al. 1988), so may changes in the nature and quantity of the diet affect GLP-1 (7-36) amide production and secretion (Göke et al. 1991).

\section{PHYSIOLOGICAL ROLE OF THE ENTERO-INSULAR AXIS}

Despite more than one-quarter of a century of intense research and an enormous amount of speculation, the physiological role of the entero-insular axis is no more clear now than when the concept was first formulated: namely that the function of the entero-insular axis is to amplify the signal to insulin secretion following the absorption of nutrients.

In this way the body is able to dispose of its single most plentiful nutrient, i.e. glucose, as expeditiously as possible and without producing unduly large perturbations in its plasma concentration (Service \& Nelson, 1980; Marks, 1987). This might not only be wasteful through losses of glucose in the urine, but would also produce undesirable osmotic effects within the body itself.

Because of their additional effects on adipose tissue, especially their ability to stimulate glucose uptake by adipocytes and accelerate its conversion into fatty acids (Morgan $e t$ al. 1991), and which are shared by insulin itself but by no other circulating hormones of which we are aware, both GIP and GLP-1 (7-36) amide seem to be ideally suited not only to encouraging the uptake of preformed fat in the diet by adipocytes but also the conversion of dietary carbohydrate into fat. This is the most economical way of storing dietary energy, whether taken as fat or carbohydrate, against a time when food might not be available due to drought or famine.

\section{PATHOLOGY AND MALFUNCTIONING OF THE ENTERO-INSULAR AXIS}

If the physiological role of the entero-insular axis is poorly understood, its pathology is equally or more so. The possibility that some or all of the features of non-insulindependent diabetes mellitus might be explained by entero-insular malfunction was soon dispelled (Marks \& Samols, 1970), and at this time no well characterized disease of man can be laid firmly at the door of the entero-insular axis.

The possibility that increased activity of the entero-insular axis, especially of GIP secretion, might be involved in the pathogenesis of some types of genetic and familial obesity has recently been reviewed (Marks, 1988). Briefly GIP is an anabolic hormone which stimulates the secretion of insulin and itsclf favours the production of lipid from carbohydrates. It activates lipoprotein lipase $(E C 3.1 .1 .34)$, thereby favouring the uptake of absorbed triacylglycerols by adipocytes rather than by the liver. Its own production and secretion is induced by high-fat feeding (Morgan et al. 1988) and is increased in many animals as well as some human models of genetic obesity (Bailey \& Flatt, 1988; Jones et al. 1989a,b). Counter arguments to the involvement of GIP in the genesis of obesity have been advanced, but apply mainly to the sporadic rather than the genetic and familial types and, at the present time GIP, with or without GLP-1(7-36) amide, remains the main candidate for the role of humoral mediator of obesity if indeed one does exist (Marks, 1988). 
Glucagon-like peptides of one sort or another have been implicated in the pathogenesis of severe and clinically important reactive hypoglycaemia (Samols \& Marks, 1967; Bloom et al. 1972; Block et al. 1977; Charles \& Waldeck, 1981), but whether, as now seems likely, it is due to GLP-1(7-36) amide awaits investigation with the newer specific assays that have become available.

\section{REFERENCES}

Andersen, D. K.. Elahi, D.. Brown, J. C., Tobin, J. D. \& Andres, R. (1978). Oral glucose augmentation of insulin secretion. Journal of Clinical Investigation 62, 152-161.

Arendt, J., Hampton, S., English, J., Kwasowski, P. \& Marks, V. (1982). 24-hour profiles of melatonin, cortisol, insulin, C-peptide and GIP following a meal and subsequent fasting. Clinical Endocrinology 16, 89-95.

Bailey, C. J. \& Flatt. P. R. (1988). The enteroinsular axis in animals with hyperinsulinaemic and hypoinsulinaemic diabetes. Frontiers in Diabetes Research II, pp. 217-224 [E. Shafrir and A. E. Renold, editors]. London: John Libbey and Co.

Block, M. B., Hofeldt, F. D., Lufkin, E. G., Haglar, L. \& Herman, R. H. (1977). The response of glucagon-like immunoreactivity to reactive hypoglycemia. Military Medicine 142, 32-37.

Bloom, S. R., Royston, C. M. S. \& Thomson, J. P. S. (1972). Enteroglucagon release in the dumping syndrome. Lancet ii, 789-793.

Brown, J. C. (1982). Gastric Inhibitory Polypeptide. Heidelberg \& New York: Springer-Verlag.

Brown, J. C. \& Dryburgh, J. R. (1971). A gastric inhibitory polypeptide II: the complete amino acid sequence. Canadian Journal of Biochemistry 49, 867-872.

Brown, J. C., Mutt, V. \& Pederson, R. A. (1970). Further purification of a polypeptide demonstrating enterogastrone activity. Journal of Physiology 209, 57-64.

Charles, M. A. \& Waldeck, N. (1981). Excessive circulating large molecular weight immunoreactive glucagon components in subjects with the idiopathic postprandial syndrome. Journal of Clinicul Endocrinology and Metabolism 53, 366-371.

Creutzfeldt, W. (1979). The incretin concept today. Diabetologia 16. 75-85.

Creutzfeldt, W. \& Ebert, R. (1985). New developments in the incretin concept. Diabetologia 28, 565-573.

Dupré, J., Ross, S. A., Watson, D. \& Brown, J. C. (1973). Stimulation of insulin secretion by gastric inhibitory polypeptide in man. Journal of Clinical Endocrinology and Metabolism 37, 826-828.

Ebert, R. \& Creutzfeldt, W. (1982). Influence of gastric inhibitory polypeptide antiserum on glucosestimulated insulin secretion in rats. Endocrinology 111, 1601-1606.

Elahi, D., Andersen, D. K., Muller, D. C., Tobin, J. D., Brown, J. C. \& Andres, R. (1984). The enteric enhancement of glucose-stimulated insulin release: the role of GIP in aging, obesity and non-insulindependent diabetes mellitus. Diabetes 33, 950-957.

Foster, G. L. (1923). Studies on carbohydrate metabolism: I. Some comparisons of blood sugar concentration in venous blood and finger prick blood. Journal of Biological Chemistry 55, 291-302.

Göke, R., Fchmann, H.-C. \& Göke, B. (1991). Glucagon-like peptide-1 (7-36) amide is a new incretin/ enterogastrone candidate. European Journal of Clinical Investigation 21, 135-144.

Hampton, S. M. Morgan, L. M., Tredger, J. A., Cramb, R. \& Marks, V. (1986). Insulin and C-peptide levels after oral and intravenous glucose: contribution of enteroinsular axis to insulin secretion. Diabetes 35 , $612-616$.

Holst, J. J., Ørskov, C. \& Bersani, M. (1991). Heterogeneity of islet hormones. In The Endocrine Pancreas, pp. 125-149 [E. Samols, editor]. New York: Raven Press.

Jones, I. R., Owens, D. R., Luzio, S. D. \& Hayes, T. M. (1989a). Obesity is associated with increased post-prandial GIP levels which are not reduced by dietary restriction and weight loss. Diabete \& Métabolisme (Paris) 15, 11-22.

Jones, I. R., Owens, D. R. Luzio, S. \& Hayes, T. M. (1989b). Glucose dependent insulinotropic polypeptide (GIP) infused intravenously is insulinotropic in the fasting state in Type 2 (non-insulin-dependent) diabetes mellitus. Hormone Metabolism Research 21. 23-26.

Komatsu, R., Matsuyama, T., Namba, M., Wanatabe, N., Itoh, H., Kono, N. \& Tarui. S. (1989). Glucagonostatic acid insulinotropic action of glucagon-like peptide 1 (7-36) amide. Diabetes 38, $902-905$.

Kreymann, B., Ghatei, M. A., Williams, G. \& Bloom, S. R. (1987). Glucagon-like peptide- 1 (7-36): a physiological incretin in man. Lancet ii, 1300-1304. 
McIntyre, N., Holdsworth, C. D. \& Turner, D. S. (1964). New interpretation of oral glucose tolerance. Lancet ii, $20-21$.

Makman, M. H. \& Sutherland, E. W. (1964). Use of liver adenyl cyclase for assay of glucagon in human gastrointestinal tract and pancreas. Endocrinology $75,127-1.34$.

Marks, V. (1970). The effect of fructose and galactosc on insulin secretion in man. Proceedings of an International Symposium on the Clinical and Metabolic Aspects of Laevulose, pp. 37-41. Crewe: Calmic Lid.

Marks, V. (1987). Glycaemic stability in healthy subjects: fluctuations in blood glucose concentration during the day. In Hypoglycemia: Serono Symposia Publications no. 38, pp. 19-24 [D. Andreani, V. Marks and P. J. Lefebvre, editors]. New York: Raven Press.

Marks, V. (1988). GIP-the obesity hormonc. In Current Approaches: Obesity [W. P. T. James and S. W. Parker, cditors]. London: Duphar Laboratories.

Marks, V. \& Morgan. L. (1984). The entero-insular axis. In Recent Advances in Diabetes. pp. 55-71. [M. Nattrass and J. V. Santiago, editors]. Edinburgh: Churchill Livingstone.

Marks, V. \& Samols. E. (1970). Intestinal factors in the regulation of insulin secretion. Advances in Metabolic Disorders 4, 1-38.

Marks, V. \& Turner, D. S. (1977). The gastrointestinal hormones with particular reference to their role in the regulation of insulin secretion. Essays in Medical Biochemistry 3. 109-152.

Morgan, L. M., Morris, B. A. \& Marks, V. (1978). Radioimmunoassay of gastric inhibitory polypeptide. Annals of Clinical Biochemistry 15, 172-177.

Morgan, L. M., Oben, J., Fletcher, J. \& Marks, V. (1991). Metabolic effects of gut peptides. In Control of Lean and Fat Deposition - 51st Easter School in Agricultural Science, Nortingham University (In the Press).

Morgan. L. M., Tredger, J. A. T., Hampton. S. M. French, A. P. Peake, J. C. F. \& Marks, V. (1988). The effect of dietary modification and hyperglycaemia in gastric emptying and gastric inhibitory polypeptide (GIP) secretion. British Journal of Nutrition 60, 29-37.

Morgan, L. M.. Wright. J. W. \& Marks, V. (1979). The effect of oral galactose on GIP and insulin secretion in man. Diabetologia 16, 235-239.

Peters, J. P. \& van Slyke, D. D. (1946). Quantitative Clinical Chemistry Interpretations, vol. 1. London: Baillière, Tindall \& Cox.

Samols, E., Tyler, J., Marri, G. \& Marks. V. (1965). Stimulation of glucagon secretion by oral glucose. Lancet ii, $1257-1259$.

Samols. E. \& Marks, V. (1967). Nouvelles conceptions sur la signification fonctionnelle du glucagon (pancréatique ct extrapancréatique). Journées annuelles de Diabétologie de l'Hotel-Dieu, pp. 43-46. Paris: Editions Médicales Flammarion.

Samols, E. \& Stagner, J. I. (1991). Intraislet and islet-acinar portal systems and their significance. In The Endocrine Pancreas, pp. 93-124 [E. Samols, editor]. Ncw York: Raven Press.

Samols, E., Tyler, J., Megyesi, C.\& Marks. V. (1966). Immunochemical glucagon in human pancreas, gut and plasma. Lancet ii, 727-729.

Sarson, D. L.. Wood, S. M., Holder. D. \& Bloom, S. R. (1982). The effect of glucose-dependent insulinotropic polypeptide infused at physiological concentrations on the release of insulin in man. Diabetologia 22, 33-36.

Service, F. J. \& Nelson, R. L. (1980) Characteristics of glycemic stability. Diabetes Care 3, 58-62.

Shuster, L. T.. Go, V. L. W., Rizza, R. A. O'Bricn, P. C. \& Service. F. J. (1988). Potential incretins. Mayo Clinic Proceedings 63, 794-800.

Sykes, S., Morgan. L. M. English, J. \& Marks, V. (1980). Evidence for the preferential stimulation of gastric inhibitory polypeptide secretion in the rat by actively transported carbohydrates and their analogues. Journal of Endocrinology 85, 201-207.

Takemura, J.. Seino, Y., Yamamura, T.. Tsuda, K., Seino, S., Itoh, N. \& Imura. H. (1982). The role of endogenous gastric inhibitory polypeptide in the enteroinsular axis. Journal of Clinical Endocrinology and Metabolism 54, 909-913.

Taminato. T., Seino, Y.. Goto, Y., Inoue, Y., Kadowaki, S., Mori, K., Nozawa, M., Yajima, H. \& Imura, H. (1977). Synthetic gastric inhibitory polypeptide: stimulatory effect on insulin and glucagon secretion in the rat. Diabetes 26, 48()-484.

Turner, D. S.. Etheridge, L., Marks, V., Brown. J. C. \& Mut, V. (1974). Effectiveness of the intestinal polypeptides. IRP, GIP, VIP and Motilin on insulin release in the rat. Diabetologia 10, 459-463.

Turner. D. S. Shabaan, A., Etheridge. L. \& Marks, V. (1973). The effect of an intestinal polypeptide fraction on insuiin release in the rat in vitro and in vivo. Endocrinology 93, 1323-1328.

\section{Printed in Great Britain}

